\title{
Identifikasi Model Mental Siswa Pada Materi Perpindahan Kalor di SMA Negeri 5 Palu
}

\author{
Ni Wayan Yudani, Marungkil Pasaribu dan I Wayan Darmadi \\ niwayanyudani@gmail.com \\ Program Studi Pendidikan Fisika FKIP Universitas Tadulako \\ Jl. Soekarno Hatta Km. 9 Kampus Bumi Tadulako Tondo Palu - Sulawesi Tengah
}

\begin{abstract}
Abstrak - Penelitian ini bertujuan untuk mendeskripsikan model mental yang digunakan siswa dalam menjelaskan konsep perpindahan kalor di SMAN 5 Palu. Jenis penelitian ini adalah deskriptif kualitatif. Lokasi penelitian ini dilaksanakan di SMAN 5 Palu. Subyek penelitian ini adalah siswa kelas XI IPA 1 dan XI IPA 3 sebanyak 54 orang yang diberikan tes diagnostik 2 tingkat (two tier). Tingkat I untuk mengetahui pemahaman siswa, tingkat II untuk mengidentifikasi model mental. Responden dipilih sebanyak 9 orang yang diperoleh berdasarkan hasil tes diagnostik tingkat I untuk diwawancarai lebih mendalam guna mempertegas jawaban siswa pada tes diagnostik 2 tingkat. Penelitian ini menunjukkan bahwa siswa yang memiliki kemampuan dengan kategori tinggi kecendrungan menggunakan model konveksi berbasis difusi, model konveksi berbasis difusi (beratap panas I), model konveksi berbasis difusi (beratap panas II), model konveksi arus bersepeda, model konveksi arus bersepeda (perbedaan massa jenis), model konveksi arus bersepeda (suhu didistribusikan merata), dan model konveksi fluida bergerak. Siswa yang memiliki kemampuan dengan kategori sedang kecendrungan menggunakan model konveksi fluida bergerak, model konveksi arus bersepeda, model konveksi arus bersepeda (perbedaan massa jenis), konveksi arus bersepeda (tahapan meluasnya konveksi), model konveksi fluida bergerak, dan model lain. Sedangkan siswa yang memiliki kemampuan dengan kategori rendah kecendrungan menggunakan model konveksi arus bersepeda (perbedaan massa jenis), model konveksi fluida bergerak, dan model lain.
\end{abstract}

Kata Kunci : Model Mental; Perpindahan Kalor

\section{PENDAHULUAN}

Model mental mewakili ide-ide dalam pikiran seseorang yang mereka gunakan untuk menggambarkan dan menjelaskan fenomena. Untuk menjelaskan sebuah fenomena, model mental bertindak sebagai peran "pengganti" untuk menggambarkan konsep itu. Peran pengganti konsep seseorang dalam menjelaskan fenomena inilah yang dinamakan dengan model mental. ${ }^{[1]}$

Psikologi kognitif (dalam ilmu psikologi) merupakan sebuah bidang studi tentang bagaimana manusia memahami, belajar, mengingat dan berfikir tentang suatu informasi, [2]. Model mental dapat menginformasikan tentang bagaimana system fisis bekerja, meliputi prilaku objek dalam hukum-hukum fisika. Sehingga model mental tidak hanya digunakan dalam ilmu psikologi saja, tetapi bisa digunakan dalam ilmu fisika.

Mental model telah digariskan sebagai representasi internal konsep dan ide. Menjadi keunikan dalam penelitian model mental karena siswa memiliki kerangka konsep yang berbedabeda dalam menjelaskan sebuah fenomena dalam fisika. Dengan demikian, model mental masing-masing siswa dalam menjelaskan fenomena juga berbeda-beda pula. ${ }^{[3]}$
Tujuan mengetahui model mental yang digunakan siswa adalah untuk mengetahui sejauh mana tingkat pemahaman siswa pada suatu materi yang telah di ajarkan sebelumnya. Model mental yang dimiliki siswa bagi guru sangat penting, baik untuk menentukan strategi pembelajaran yang cocok dalam pembelajaran kedepannya, bahan ajar, ataupun media yang disusun agar pemahaman siswa mengenai suatu konsep fisika menjadi suatu kesatuan yang utuh.

Penelitian ini bertujuan untuk mendeskripsikan gambaran konsep dan ide yang dimiliki oleh siswa SMA Negeri 5 Palu kelas XI IPA 3 dalam menjelaskan fenomena perpindahan kalor, khususnya perpindahan kalor secara konveksi. Model mental siswa SMA Negeri 5 Palu kelas XI IPA 3 dalam menjelaskan perpindahan kalor, khususnya perpindahan kalor secara konveksi dengan mengacu model mental yang telah di identifikasi oleh Chiou. ${ }^{[4]}$

\section{METODE PENELITIAN}

Penelitian ini merupakan penelitian deskriptif kualitatif dimana data diperoleh berdasarkan fakta-fakta yang ada di lapangan. Penelitian ini dilakukan di salah satu sekolah menengah atas di kota Palu yaitu SMA N 5 Palu. Subyek 
penelitian ini adalah siswa kelas XI IPA 1 dan XI IPA 3 di SMA N 5 Palu tahun ajaran 2015/2016 sebanyak 54 orang yang telah mengikuti pembelajaran fisika pada materi suhu dan kalor. Pemilihan responden wawancara sebanyak 9 orang yang dipilih secara purposive sampling, berdasarkan tingkat pemahaman siswa dengan kategori tinggi, sedang, rendah dapat diperoleh dari hasil tes diagnostik tingkat I (tes pemahaman siswa) dengan menghitung nilai rata-rata dan standar deviasi. Penelian ini dilakukan selama 2 minggu di bulan Oktober tahun 2015 dengan tatap muka sebanyak 2 kali.

Peneliti sebagai instrumen utama memberikan tes kepada subyek dan mengambil beberapa subyek untuk dijadikan responden yang kemudian diwawancarai lebih lanjut. Tes yang digunakan adalah tes diagnostic two tier (2 tingkat). Tes diagnostik tingkat I digunakan untuk mengetahui pemahaman konsep siswa. Tes diagnostik ini berbentuk pilihan ganda dengan 1 jawaban benar dan 3 jawaban salah. Tes diagnostik tingkat II digunakan untuk mengetahui model mental siswa. Pada tes ini, terdiri dari tiga alasan yang semuanya benar dan satu alasan kosong yang dapat diisikan siswa sesuai dengan kalimat atau bahasanya sendiri. Wawancara yang digunakan adalah wawancara semi-strukture guna mempertegas jawaban siswa sebelumnya sekaligus merefleksi serta menggali lebih dalam model mental yang dimiliki siswa.

Data-data berupa jawaban siswa dan hasil wawancara yang disajikan, dianalisis untuk mengidentifikasi model mental siswa dengan mengikuti Hrepic yaitu melalui defenisi yang disusun dari deskripsi oleh responden terhadap fenomena tertentu dan melalui seperangkat sifat-sifat fenomena yang dapat dikaitkan secara unik dengan model tertentu yang telah pernah di identifikasi peneliti lain. ${ }^{[5]}$

\section{HASIL PENELITIAN DAN PEMBAHASAN}

Model mental siswa dapat di ukur menggunakan tes diagnostik 2 tingkat yang berjumlah 5 nomor soal dengan 5 indikator soal. Tes diagnostik 2 tingkat diberikan kepada subyek penelitian yang kemudian di pilih sebanyak 9 orang responden yang masingmasing mewakili siswa yang memiliki dengan kategori tinggi sedang dan rendah. Teknik pemilihan responden ini berdasarkan perhitungan menggunakan nilai rata-rata dan standar deviasi. Sehingga penyajian hasil tes dignostik 2 tingkat responden penelitian terdapat dalam Tabel 1.

TABEL 1 Penyajian Hasil Tes Diagnostik 2 Tingkat RESPONDEN PENELITIAN

\begin{tabular}{|c|c|c|c|c|c|c|c|c|c|c|c|}
\hline \multirow{4}{*}{$\begin{array}{l}\text { Inisial } \\
\text { Nama }\end{array}$} & \multicolumn{6}{|c|}{ Tes Diagnostik } & \multirow{3}{*}{\multicolumn{5}{|c|}{$\begin{array}{l}\text { Tes Diagnostik } \\
\text { Tingkat II } \\
\text { Nomor Soal }\end{array}$}} \\
\hline & & & & Tin & $g k a$ & & & & & & \\
\hline & \multicolumn{5}{|c|}{ Nomor Soal } & \multirow[t]{2}{*}{ Kategori } & & & & & \\
\hline & 1 & 2 & 3 & 4 & 5 & & 1 & 2 & 3 & 4 & 5 \\
\hline S-01 & 1 & 1 & 1 & 1 & 1 & Tinggi & 2 & 1 & 4 & 1 & 1 \\
\hline S-02 & 1 & 1 & 1 & 1 & 1 & Tingg & 1 & 3 & 3 & 2 & 1 \\
\hline S-03 & 1 & 1 & 1 & 1 & 1 & Ting & 2 & 3 & 4 & 1 & 1 \\
\hline S- & 1 & 1 & 1 & 1 & 0 & Sed & 2 & 3 & 4 & 2 & 4 \\
\hline & 0 & 1 & 0 & 1 & 1 & Sed & 3 & 2 & 4 & 2 & \\
\hline & 0 & 1 & 0 & 1 & 1 & Sec & 2 & 2 & 1 & 1 & \\
\hline & 1 & 1 & 0 & 0 & 0 & Rer & 2 & 3 & 2 & & 2 \\
\hline & 1 & 1 & 0 & 0 & 0 & Rer & 2 & 3 & 2 & 2 & 2 \\
\hline S-54 & 1 & 0 & 0 & 0 & 0 & Rendah & 1 & 1 & 1 & 1 & \\
\hline
\end{tabular}

Keterangan :

Tes Diagnostik Tingkat I

1 : jika jawaban benar

0 : jika jawaban salah

Tes Diagnostik Tingkat II

1 : jika memilih alasan 1

2: jika memilih alasan 2

3 : jika memilih alasan 3

Responden diwawancarai secara bergantian untuk mengkonfirmasi jawaban siswa dari hasil tes diagnostik 2 tingkat yang sudah mereka jawab sebelumnya. Tes diagnostik 2 tingkat ini terdiri dari 5 konsep mengenai konveksi. Hal ini tidak mengharuskan responden menjawab secara benar tentang konsep konveksi tetapi bagaimana responden mampu menggambarkan pemahamannya mengenai konsep yang dimilikinya.

Model mental yang dimiliki siswa dalam menjelaskan konsep perpindahan kalor secara konveksi adalah pada Tabel 2 berikut. 
tabel 2 Persentase Model Mental Siswa Untuk Setiap Kategori

\begin{tabular}{|c|c|c|c|c|c|c|c|}
\hline \multirow[b]{2}{*}{ Kategori } & \multirow[b]{2}{*}{ Model Mental } & \multicolumn{5}{|c|}{ Nomor Konsep } & \multirow{2}{*}{$\begin{array}{l}\text { Rata- } \\
\text { Rata } \\
(\%)\end{array}$} \\
\hline & & $1(\%)$ & $2(\%)$ & $3(\%)$ & $4(\%)$ & $5(\%)$ & \\
\hline \multirow{7}{*}{ Tinggi } & Model Konveksi Berbasis Difusi & 0 & 0 & 0 & 66,6 & 100 & 33,32 \\
\hline & Model Konveksi Berbasis Difusi (Beratap Panas I) & 33,3 & 0 & 33,3 & 0 & 0 & 13,32 \\
\hline & Model Konveksi Berbasis Difusi (Beratap Panas II) & 0 & 33,3 & 0 & 0 & 0 & 6,66 \\
\hline & Model Konveksi Arus Bersepeda & 0 & 0 & 33,3 & 0 & 0 & 6,66 \\
\hline & $\begin{array}{l}\text { Model Konveksi Arus Bersepeda (Perbedaan Massa } \\
\text { Jenis) }\end{array}$ & 33,3 & 33,3 & 0 & 33,3 & 0 & 19,98 \\
\hline & $\begin{array}{l}\text { Model Konveksi Arus Bersepeda (Suhu Didistribusikan } \\
\text { Merata) }\end{array}$ & 0 & 33,3 & 33,3 & 0 & 0 & 13,32 \\
\hline & Model Konveksi Fluida Bergerak & 33,3 & 0 & 0 & 0 & 0 & 6,66 \\
\hline \multirow{6}{*}{ Sedang } & Model Konveksi Berbasis Difusi & 0 & 0 & 33,3 & 33,3 & 33,3 & 19,98 \\
\hline & Model Konveksi Arus Bersepeda & 0 & 33,3 & 0 & 0 & 0 & 6,66 \\
\hline & $\begin{array}{l}\text { Model Konveksi Arus Bersepeda (Perbedaan Massa } \\
\text { Jenis) }\end{array}$ & 0 & 33,3 & 0 & 66,6 & 33,3 & 26,64 \\
\hline & $\begin{array}{l}\text { Konveksi Arus Bersepeda (Tahapan Meluasnya } \\
\text { Konveksi) }\end{array}$ & 0 & 33,3 & 0 & 0 & 0 & 6,66 \\
\hline & Model Konveksi Fluida Bergerak & 33,3 & 0 & 0 & 0 & 0 & 6,66 \\
\hline & Model Lain & 66,6 & 0 & 66,6 & 0 & 33,3 & 33,3 \\
\hline \multirow{3}{*}{ Rendah } & $\begin{array}{l}\text { Model Konveksi Arus Bersepeda (Perbedaan Massa } \\
\text { Jenis) }\end{array}$ & 33,3 & 66,6 & 0 & 0 & 0 & 19,98 \\
\hline & Model Konveksi Fluida Bergerak & 66,6 & 0 & 0 & 0 & 0 & 13,32 \\
\hline & Model Lain & 0 & 33,3 & 100 & 100 & 100 & 66,66 \\
\hline
\end{tabular}

\section{Model Konveksi Berbasis Difusi}

Karakteristik model ini adalah perpindahan kalor dari konsentrasi tinggi ke konsentrasi rendah. Misalnya ketika siswa menjelaskan tentang pengaruh suhu terhadap konveksi pada air yang direbus. Dalam wawancara, S-12 mengatakan bahwa air yang panas bergerak ke atas karena kelebihan kalor. Air yang panas bergerak ke atas, ke daerah yang memiliki konsentrasi lebih rendah.

Responden juga menggunakan model ini ketika menjelaskan tentang konveksi pada asap rokok. Responden tergolong dalam model ini ketika memilih alasan nomor 1 pada tes diagnostik tingkat II, asap bergerak ke atas karena suhunya lebih tinggi dari suhu udara sekitarnya. Udara yang panas berada pada daerah yang dekat dengan sumber panas atau puntung rokok. Udara tersebut bergerak ke atas, ke daerah yang suhunya lebih rendah. Responden yang tergolong menggunakan model ini adalah S-01, S-03, dan S-27.

Begitu juga ketika menjelaskan tentang terjadinya angin darat dan angin laut. Responden dikatakan menggunakan model ini ketika memilih alasan nomor 1 pada tes diagnostik tingkat II, kalor jenis daratan (kalor jenis benda padat) lebih kecil daripada kalor jenis air laut, karenanya daratan lebih cepat panas ketika disinari matahari dan juga lebih cepat dingin ketika malam hari tiba. Pada siang hari, daratan lebih cepat panas pada siang hari. Sehingga dapat dikatakan bahwa daratan memiliki suhu yang tinggi sehingga bergerak ke atas atau bergerak dari konsentrasi tinggi ke konsentrasi rendah.

\section{Model Konveksi Berbasis Difusi (Beratap Panas I)}

Karakteristik model ini ketika responden menjelaskan bahwa kalor berpindah dari konsentrasi tinggi ke konsentrasi rendah dan bagian atas memiliki suhu tertinggi. Responden yang tergolong dalam model ini, ketika responden memilih alasan nomor 2 untuk konsep defenisi konveksi pada tes diagnostik tingkat II, perpindahan kalor secara konveksi merupakan perpindahan kalor dari satu bagian fluida ke bagian fluida lainnya oleh pergerakan fluida itu sendiri dan mempertegas argumen yang dimilikinya pada wawancara. Seperti pada air direbus yang diungkapkan oleh responden S-01, bahwa pada saat yang direbus, air akan mendidih. Jika kita meletakkan tangan di atas air, maka tangan akan merasakan uap air tersebut.

Begitu juga ketika menjelaskan konsep pengaruh suhu konveksi pada air yang direbus. Responden S-01 ketika mengatakan bahwa konveksi tidak akan terjadi dalam waktu yang sebentar. Pada saat zat dipanaskan dalam waktu yang sebentar, maka volume air tersebut 
tidak akan memuai, volume akan memuai jika dipanaskan dalam waktu yang tepat. Ketika air dipanaskan pada bagian bawah, bagian atas adalah yang terpanas.

\section{Model Konveksi Berbasis Difusi (Beratap} Panas II)

Model ini digunakan ketika siswa memilih alasan nomor 1 pada tes diagnostik II tingkat untuk konsep mekanisme konveksi pada air yang direbus. Mekanisme penyebaran panas mirip dengan penyebaran panas secara difusi dan didukung argumen ketika diwawancarai. Responden yang tergolong dalam model ini adalah S-01 yang mengatakan bahwa pada air yang direbus, mula-mula air panas pada bagian bawah cairan karena dekat dengan sumber panas. Setelah titik didih tertentu, air yang panas pada bagian bawah bergerak ke atas dan mengeluarkan uap. Sehingga dapat disimpulkan bahwa mekanisme pada air direbus yang digunakan responden ini adalah konveksi berbasis difusi. Air yang panas pertama berada pada bagian bawah cairan, dan air panas yang kedua berada pada bagian atas cairan.

\section{Model Konveksi Arus Bersepeda \\ Model mental merupakan model paling banyak digunakan oleh siswa dalam} menjelaskan konsep konveksi. Karakteristik model ini air yang panas bergerak ke atas dan air yang dingin bergerak ke bawah. Model ini hanya berfokus pada arah penyebaran panas tanpa memperhatikan apa yang menyebabkan air panas bergerak ke atas dan air yang dingin bergerak ke bawah. Responden yang tergolong dalam model ini adalah responden yang memilih alasan nomor 2 pada tes diagnostik tingkat II untuk konsep mekanisme konveksi pada air yang direbus. Contohnya seperti responden S-26. Ketika menjelaskan pengaruh suhu terhadap konveksi, responden yang menggunakan model ini adalah responden S02.

\section{Model Konveksi Arus Bersepeda (Perbedaan Massa Jenis)}

Model ini sama halnya dengan model konveksi arus bersepeda yaitu air yang panas bergerak ke atas dan air yang dingin bergerak ke bawah. Tetapi perbedaannya terdapat pada bagaimana penyebab arus konveksi (air yang panas bergerak ke atas, air yang dingin bergerak ke bawah). Penyebab arus konveksi adalah perbedaan massa jenis zat. Responden yang menggunakan model ini adalah responden
S-02, S-54 ketika menjelaskan tentang defenisi konveksi dimana memilih alasan nomor 1 pada tes diagnostik tingkat II yaitu perpindahan kalor secara konveksi disebabkan oleh perbedaan massa jenis zat.

Untuk konsep mekanisme konveksi pada air yang direbus, responden yang tergolong model ini ketika responden memilih alasan nomor 3 pada tes diagnostik II tingkat, air yang panas memiliki massa jenisnya berkurang dan bergerak ke atas dan begitu sebaliknya. Responden yang tegolong dalam model ini adalah S-02, S-12, S-47 dan S-48.

Sama halnya dengan ketika menjelaskan konsep konveksi pada asap rokok. Responden yang menggunakan model ini ketika memilih alasan nomor 2 pada tes diagnostik II massa jenis asap yang lebih kecil mengakibatkan udara disekitar asap menekan asap ke atas. Konveksi pada asap rokok, udara panas di dekat api akan memuai sehingga massa jenisnya menjadi kecil. Responden yang tergolong dalam model ini adalah S-02, S-12 dan S-26.

6. Model Konveksi Arus Bersepeda (Suhu Didistribusikan Merata)

Karakteristik model ini adalah air yang panas bergerak ke atas dan air yang dingin bergerak ke bawah membentuk arus bersepeda sehingga suhu cairan menjadi sama. Model ini digunakan oleh responden S-03 ketika menjelaskan konsep mekanisme konveksi dan konsep pengaruh suhu pada air yang direbus. Seperti hasil wawancara dengan responden S-03 bahwa pada air yang direbus, mula-mula suhu awal pada air adalah sama. Tetapi setelah dipanasi pada bagian bawah, suhu pada bagian yang dekat dengan sumber panas, akan panas terlebih dahulu dan bergerak ke atas dan suhu yang mulanya berada di atas bergerak kebawah. Begitu seterusnya sehingga suhu air menjadi rata.

\section{Model Konveksi Arus Bersepeda (Tahapan Meluasnya Konveksi)}

Karakteristik model ini ketika air dipanaskan pada bagian bawah, air panas bergerak ke atas, air yang dingin bergerak ke bawah membentuk arus bersepeda. Arus bersepeda dimulai dari bagian bawah cairan kemudian menyebar ke bagian atas cairan sehingga suhu cairan menjadi sama. Responden S-27 menggunakan model ini dalam menjelaskan konveksi.

Responden ini mengatakan bahwa ketika air dipanaskan pada bagian bawah, suhu yang 
berada pada bagian bawah cairan meningkat dan meyebabkan air panas bergerakan atau memiliki arus seperti menghasilkan gelembunggelembung kecil. Tahapan meluasnya model ini, yaitu dari gerakan arus bersepeda yang dimulai dari arus bersepeda kecil pada bagian bawah cairan dan secara bertahap naik ke atas dan akhirnya memiliki suhu yang sama dalam cairan.

\section{Model Konveksi Fluida Bergerak}

Model ini digunakan ketika siswa menjelaskan defenisi konveksi dan memilih alasan nomor 2 pada tes diagnostik tingkat II, perpindahan kalor secara konveksi merupakan perpindahan kalor dari satu bagian fluida kebagian fluida lainnya oleh pergerakan fluida itu sendiri. Model ini hanya mengacu pada pergerakan fluida tanpa memperhatikan arah gerakan fluida itu sendiri. responden yang tegolong dalam model ini adalah responden S-03, S-12, S-47 dan S48.

\section{Model Lain}

Model lain adalah model yang dimilki siswa selain model mental yang telah diidentifikasi. Responden yang tergolong dalam model ini adalah responden yang tidak tepat menjawab tes diagnostik maupun wawancara. Model lain juga bisa di anggap bahwa siswa yang tergolong dalam model ini adalah siswa yang mengalami cacat mental.

Identifikasi model mental yang digunakan siswa dalam menjelaskan konsep perpindahan kalor berjumlah 9 jenis model mental. Pada umumnya, model yang digunakan siswa dalam menjelaskan konsep perpindahan kalor ada 4 jenis yaitu model konveksi berbasis difusi, model konveksi arus bersepeda, model konveksi fluida bergerak dan model lain. Hanya saja di dalam menjelaskan fenomena konveksi, responden memiliki macam-macam argumen dalam mendeskripsikan pemikirannya, khususnya meraka yang memiliki model mental konveksi berbasis difusi dan model konveksi seperti arus bersepeda.

Model mental siswa adalah gambaran konsep yang ada dibenak siswa untuk menjelaskan suatu situasi atau proses yang sedang terjadi, [6]. Perbedaan model mental yang dimiliki oleh siswa pada masing-masing kategori, tergantung dari bagaimana siswa membentuk model mentalnya.

Model mental dibangun dari persepsi, imajinasi, atau dari pemahaman wacana, [7].
Sejalan dengan sebuah pendapat bahwa model mental siswa dipengaruhi oleh model ilmiah/consencus dan model pengajar, ${ }^{[8]}$. Model pengajar adalah sesuatu yang mutlak harus diperhatikan oleh seorang guru dalam pembentukan model mental siswanya. Model pengajar diartikan sebagai peran serta seorang guru dalam mengelola kelas, menyiapkan model pembelajaran yang cocok untuk mengajar bagi siswa yang memiliki karakter atau model mental seperti yang sudah di identifikasi dalam penelitian ini.

Kesulitan-kesulitan yang di alami oleh siswa, dapat diperbaiki dengan model pembelajaran yang akan digunakan seorang guru. Model pembelajaran yang cocok digunakan untuk karakter siswa tersebut adalah model discovery. Discovery adalah pengajaran di mana guru memberikan kebebasan siswa untuk menemukan sesuatu sendiri. Sehingga siswa dapat lebih mengerti secara mendalam. Dengan menemukan sendiri, siswa akan sampai pada pengalaman gembira "AHA! Aku menemukan!" siswa akan menjadi senang. Siswa belajar melalui keterlibatan aktif dengan konsep dan prinsip-prinsip. Siswa didorong untuk mempunyai pengalaman dan melakukan percobaan yang memungkinkan mereka menemukan prinsip-prinsip atau pengetahuan bagi dirinya.

\section{KESIMPULAN}

Berdasarkan hasil penelitian dan pembahasan dapat disimpulkan bahwa siswa yang memiliki kemampuan dengan kategori tinggi memiliki kecendrungan menggunakan Model Konveksi Berbasis Difusi, Model Konveksi Berbasis Difusi (Beratap Panas I), Model Konveksi Berbasis Difusi (Beratap Panas II), Model Konveksi Arus Bersepeda, Model Konveksi Arus Bersepeda (Perbedaan Massa Jenis), Model Konveksi Arus Bersepeda (Suhu Didistribusikan Merata), dan Model Konveksi Fluida Bergerak.

Siswa yang memilki kemampuan dengan kategori sedang memiliki kecendrungan menggunakan Model Konveksi Fluida Bergerak, Model Konveksi Arus Bersepeda, Model Konveksi Arus Bersepeda (Perbedaan Massa Jenis), Konveksi Arus Bersepeda (Tahapan Meluasnya Konveksi), Model Konveksi Fluida Bergerak, dan Model Lain.

Sedangkan siswa yang memilki kemampuan dengan kategori rendah memiliki kecendrungan menggunakan Model Konveksi Arus Bersepeda 
(Perbedaan Massa Jenis), Model Konveksi Fluida Bergerak, dan Model Lain.

\section{DAFTAR PUSTAKA}

[1] Jansoon, N. (2009). "Understanding Mental Models of Dilution in Thai Students". International Journal of Environmental \& Science Education. 4(2), 147-168.

[2] Rahayu, S. (2013). Identifikasi Model Mental Siswa SMA Kelas $X$ Pada Materi Hukum Newton Tentang Gerak. [Online]. Diakses tanggal 11 Januari 2015.

[3] Gilbert, J. K. (2005). Mental Models: Theoretical Issues For Visualizations In Science Education. [Online], (Diakses tanggal 15 Januari 2015)

[4] Chiou, G. (2013). "Reappraising the relationships between physics students' mental models and predictions: An example of heat convection". Physics Education Research 9(1) : 010-119.

[5] Hrepic, Z. (2010). "Identifying Students' Mental Models of Sound Propagation: The Role Of Conceptual Blending In Understanding Conceptual Change". Physics Education Research. 6(2), 1-18.

[6] Greca, IM \& Moreira MA, (2000). "Mental Models, Conceptual Models, And Modeling". International Journal Science Education, 22(1), 1-11.

[7] Laliyo, L. A. R. (2011). "Model Mental Siswa dalam Memahami Perubahan Wujud Zat", Jurnal Penelitian dan Pendidikan, 8(1), 1-12

[8] Junaina. (2012). Pengaruh Pembelajaran Kerangka Ifso Terhadap Peningkatkan Model Mental Dan Penguasaan Konsep Ikatan Kimia Siswa. [Online]. Diakses tanggal 15 Novemver 2015. 